\title{
PELANGGARAN ASAS KEPASTIAN HUKUM DALAM PENYELESAIAN \\ SENGKETA PEMILIHAN KEPALA DAERAH \\ DI KABUPATEN TOBA SAMOSIR
}

\author{
Tengku Erwinsyahbana \\ Fakultas Hukum Universitas Muhammadiyah Sumatera \\ E-mail: tengkuerwins@umsu.ac.id
}

\begin{abstract}
Abstrak
Pelaksanaan Pilkada serentak di Propinsi Sumatera Utara, ternyata masih menimbulkan berbagai persoalan, hal ini diasumsikan karena berbagai faktor, antara lain terkait dengan ketidakpahaman Penyelenggara Pemilu terhadap berbagai regulasi dalam bidang kepemiluan. Sebagai contoh yang dapat diambil adalah kasus pelanggaran kode etik yang dilakukan oleh Panwas Kabupaten Toba Samosir. Kasus ini diawali dari keputusan KPU yang tidak menetapkan Monang Sitorus dan Chrissie Sagita Hutahean dari jalur calon perseorangan sebagai Pasangan Calon dalam Pemilihan Bupati Kabupaten Toba Samosir (karena tidak memenuhi persyaratan), yang pada akhirnya menimbulkan sengketa Pilkada.
\end{abstract}

Kata Kunci: Kepala Daerah, Kepastian Hukum, Sengketa

\section{A. Latar Belakang}

Pemilihan Kepala Daerah dan Wakil Kepala Daerah (Pilkada) secara langsung, didukung semangat otonomi daerah yang telah digulirkan sejak tahun 1999, sedangkan mulai tahun 2015, Pilkada dilaksanakan secara serentak hampir di seluruh wilayah Negara Kesatuan Republik Indonesia. Pilkada secara langsung masih menimbulkan berbagai persoalan, walaupun Pemerintah telah beberapa kali mengganti peraturan perundang-undangan yang terkait dengan penyelenggaraan Pilkada, dan terakhir adalah dengan keluarnya Undangundang Nomor 8 Tahun 2015 tentang Perubahan Atas Undang-undang Nomor 1 Tahun 2015 tentang Penetapan Peraturan Pemerintah Pengganti Undangundang Nomor 1 Tahun 2014 tentang Pemilihan Gubernur, Bupati, dan Walikota Menjadi Undang-undang (UU No. 8 Tahun 2015). 
Sesuai UU No. 8 Tahun 2015, pada tanggal 9 Desember 2015, di Propinsi Sumatera Utara diselenggarakan Pilkada secara serentak untuk 23 kabupaten/ kota, yaitu: Kota Medan, Kabupaten Serdang Bedagai, Kabupaten Tapanuli Selatan, Kabupaten Toba Samosir, Kota Binjai, Kabupaten Labuhan Batu, Kabupaten Asahan, Kota Sibolga, Kabupaten Pakpak Bharat, Kabupaten Humbang Hasundutan, Kabupaten Samosir, Kota Pematangsiantar, Kabupaten Simalungun, Kabupaten Labuhanbatu Utara, Kabupaten Mandailing Natal, Kabupaten Karo, Kota Tanjung Balai, Kabupaten Nias, Kabupaten Nias Selatan, Kabupaten Labuhan Batu Selatan, Kabupaten Nias Utara, Kabupaten Nias Barat dan Kota Gunung Sitoli.

Pelaksanaan Pilkada serentak di Propinsi Sumatera Utara, ternyata masih menimbulkan berbagai persoalan, hal ini diasumsikan karena berbagai faktor, antara lain terkait dengan ketidakpahaman Penyelenggara Pemilu terhadap berbagai regulasi dalam bidang kepemiluan. Sebagai contoh yang dapat diambil adalah kasus pelanggaran kode etik yang dilakukan oleh Panwas Kabupaten Toba Samosir.

Kasus ini diawali dari keputusan KPU yang tidak menetapkan Monang Sitorus dan Chrissie Sagita Hutahean dari jalur calon perseorangan sebagai Pasangan Calon dalam Pemilihan Bupati Kabupaten Toba Samosir (karena tidak memenuhi persyaratan), yang pada akhirnya menimbulkan sengketa Pilkada. Berdasarkan hasil pemeriksaan sengketa yang dilaksanakan, dalam putusannya Panwas Kabupaten Toba Samosir secara sepihak telah menetapkan Monang Sitorus dan Chrissie Sagita Hutahean sebagai pasangan calon dalam Pilkada Kabupaten Toba Samosir. Persoalan yang muncul dari kasus ini adalah terkait dengan kewenangan Panwas untuk menetapkan pasangan calon tersebut dalam Pemilihan Bupati Kabupaten Toba Samosir, padahal dalam UU No. 8 Tahun 2015, tidak ada ketentuan yang memberikan kewenangan bagi Bawaslu berikut jajaran ke bawah untuk menetapkan bakal calon sebagai calon dalam Pilkada, sehingga Panwas Kabupaten Toba Samosir telah diadukan ke Dewan 
Kehormatan Penyelenggara Pemilu Republik Indonesia (DKPP-RI) dengan tuduhan melakukan pelanggaran etika kepemiluan.

\section{B. Etika dalam Penyelenggaraan Pemilu}

Etika merupakan ilmu dan termasuk cabang dari filsafat yang paling tua sejak zaman Yunani Kuno. Etika adalah refleksi kritis, metodis, dan sistematis tentang tingkah laku manusia yang berkaitan dengan norma-norma atau tentang tingkah laku manusia dari sudut kebaikannya. Hal yang dibicarakan dan dianalisis dalam etika, adalah tema-tema sentral mengenai hati nurani, kebebasan, tanggung jawab, norma, hak dan kewajiban, serta nilai-nilai kebaikan. Lazimnya pengertian etika dirumuskan sebagai nilai-nilai dan normanorma moral yang dipegang oleh seseorang atau sekelompok orang dalam masyarakat untuk mengatur tingkah lakunya, yang bertujuan untuk menciptakan hubungan antar manusia dalam masyarakat secara harmonis, dan oleh sebab itu "etika" selalu menuntun orang agar bersungguh-sungguh menjadi baik, agar memiliki sikap etis.

Terkait dengan Kode Etik Penyelenggara Pemilu, maka terhadap istilah "Kode Etik", diartikan sebagai satu kesatuan landasan norma moral, etis dan filosofis yang menjadi pedoman bagi perilaku penyelenggara pemilihan umum yang diwajibkan, dilarang, patut atau tidak patut dilakukan dalam semua tindakan dan ucapan. Adapun tujuan kode etik ini adalah untuk menjaga kemandirian, integritas, dan kredibilitas Penyelenggara Pemilu, yang sesuai dengan asas Penyelenggaraan Pemilu, yaitu: (1) mandiri; (2) jujur; (3) adil; (4) kepastian hukum; (5) tertib; (6) kepentingan umum; (7) keterbukaan; (8) proporsionalitas; (9) profesionalitas; (10) akuntabilitas; (11) efisiensi; dan (12) efektivitas. Keduabelas asas ini dituangkan dalam Peraturan Bersama Komisi Pemilihan Umum, Badan Pengawas Pemilihan Umum, dan Dewan Kehormatan Penyelenggara Pemilihan Umum Nomor 13 Tahun 2012, Nomor 11 Tahun 2012, 
Nomor 1 Tahun 2012 tentang Kode Etik Penyelenggara Pemilihan Umum (dalam tulisan ini selanjutnya disebut Peraturan Kode Etik Pemilu).

Terkait dengan judul tulisan ini, maka yang perlu diuraikan adalah tentang asas kepastian hukum, yang berdasarkan Peraturan Kode Etik Pemilu ditentukan bahwa dalam melaksanakan asas kepastian hukum, Penyelenggara Pemilu berkewajiban untuk: (1) melakukan tindakan dalam rangka penyelenggaraan Pemilu yang secara tegas diperintahkan oleh peraturan perundangundangan; (2) melakukan tindakan dalam rangka penyelenggaraan Pemilu yang sesuai dengan yurisdiksinya; (3) melakukan tindakan dalam rangka penyelenggaraan Pemilu, menaati prosedur yang ditetapkan dalam peraturan perundang-undangan; dan (4) menjamin pelaksanaan peraturan perundangundangan yang berkaitan dengan Pemilu sepenuhnya diterapkan secara tidak berpihak dan adil.

\section{Konsep Kepastian Hukum dalam Perspektif Teori}

Pertanyaan mendasar tentang keberadaan hukum di masyarakat, selalu terkait dengan bangunan hukum dalam suatu sistem dan hal ini tentunya diperlukan untuk menjamin terciptanya kepastian hukum itu sendiri dalam kehidupan sosial masyarakat. Persoalan kepastian hukum masih menjadi hambatan dalam kegiatan penyelenggaraan negara dan pembangunan, serta termasuk pula dalam penyelenggaraan Pemilu di Indonesia. Hal ini terjadi karena peraturan perundang-undangan yang masih tumpang tindih, tidak konsisten, tidak jelas atau multitafsir, bahkan karena rendahnya pemahaman penyelenggara negara atau masyarakat terhadap aturan hukum itu sendiri.

Banyak aspek yang terkait dengan kehidupan masyarakat telah diwujudkan dalam bentuk undang-undang demi menjamin terciptanya kepastian hukum, tetapi faktanya walaupun diwujudkan dalam bentuk undang-undang, ternyata dalam pengimplementasinya tidak dipatuhi. Salah satu faktor tidak dipatuhinya undang-undang, karena ketidakpahaman terhadap aturan hukum, 
dan oleh sebab itu guna mewujudkan kepastian hukum tidaklah dapat dilakukan hanya dengan membentuknya dalam undang-undang.

Terhadap istilah kepastian hukum, menurut Sudikno Mertokusumo (1993: 1) merupakan perlindungan yustisiabel terhadap tindakan sewenangwenang yang berarti bahwa seseorang akan dapat memperoleh sesuatu yang diharapkan dalam keadaan tertentu, sedangkan menurut Pusat Bahasa Departemen Pendidikan Nasional (2002: 835) disebutkan bahwa kepastian hukum adalah perangkat hukum suatu negara yang mampu menjamin hak dan kewajiban setiap warga negara. Budiono Kusumohamidjojo (1999: 153) membedakan antara: (1) Kepastian dalam orientasi bagi masyarakat (orientierungssicherbeit/certitudo); dan (2) Kepastian dalam penetapan hukum oleh penegak hukum (realisierungssicherbeir/securitas). Demikian juga Reinhold Zippelius sebagaimana dikutip Franz Magnis Suseno (2001: 79) juga membedakan kepastian hukum dalam 2 (dua) pengertian, yaitu: (1) Kepastian dalam pelaksanaannya, maksudnya bahwa hukum yang resmi diundangkan dilaksanakan dengan pasti oleh negara. Setiap orang dapat menuntut agar hukum dilaksanakan dan tuntutan itu pasti dipenuhi dan setiap pelanggaran hukum akan ditindak dan dikenakan sanksi menurut hukum juga; dan (2) Kepastian orientasi, maksudnya bahwa hukum itu harus jelas, sehingga masyarakat dan hakim dapat berpedoman padanya. Hal ini berarti bahwa setiap istilah dalam hukum harus dirumuskan dengan terang dan tegas sehingga tak ada keragu-raguan tentang tindakan apa yang dimaksud. Begitu pula aturanaturan hukum harus dirumuskan dengan ketat dan sempit agar keputusan dalam perkara pengadilan tidak dapat menurut tafsiran subyektif dan selera pribadi hakim. Kepastian orientasi menuntut agar ada prosedur pembuatan dan peresmian hukum yang jelas dan dapat diketahui umum. Kepastian orientasi ini juga menuntut agar hukum dikembangkan secara kontinu dan taat asas. Undang-undang harus saling kait mengkait, harus menunjuk ke satu arah agar 
masyarakat dapat membuat rencana ke masa depan, begitu pula jangan dibuat undang-undang yang saling bertentangan.

\section{Penerapan Asas Kepastian Hukum dalam Penyelesaian Sengketa}

Berdasarkan Pasal 30 Undang-undang Nomor 8 Tahun 2015 tentang Perubahan Atas Undang-undang Nomor 1 Tahun 2015 tentang Penetapan Peraturan Pemerintah Pengganti Undang-undang Nomor 1 Tahun 2014 tentang Pemilihan Gubernur, Bupati, dan Walikota Menjadi Undang-undang (selanjutnya disingkat UU No. 8 Tahun 2015), ditentukan bahwa tugas dan wewenang Panwas Kabupaten/Kota adalah: (1) mengawasi tahapan penyelenggaraan pemilihan; (2) menerima laporan dugaan pelanggaran terhadap pelaksanaan peraturan perundang-undangan mengenai pemilihan; (3) menyelesaikan temuan dan laporan sengketa penyelenggaraan pemilihan yang tidak mengandung unsur tindak pidana; (4) menyampaikan temuan dan laporan kepada KPU Provinsi dan KPU Kabupaten/Kota untuk ditindaklanjuti; dan (5) meneruskan temuan dan laporan yang bukan menjadi kewenangannya kepada instansi yang berwenang. Atas dasar ketentuan ini, maka Panwas telah diberikan amanah oleh undang-undang untuk menyelesaikan sengketa yang terjadi dalam penyelenggaraan pemilihan Kepala Daerah, yang tidak termasuk dalam pelanggaran pidana.

Seperti yang diuraikan sebelumnya bahwa di Kabupaten Toba Samosir telah terjadi sengketa dalam proses pemilihan Kepala Daerah, yang diawali dari keputusan KPU yang tidak menetapkan Monang Sitorus dan Chrissie Sagita Hutahean dari jalur calon perseorangan sebagai Pasangan Calon dalam Pemilihan Bupati, karena tidak memenuhi persyaratan sebagai pasangan calon. Panwas Kabupaten Toba Samosir, telah memeriksa perkara tersebut, dan dalam putusannya Panwas menetapkan Monang Sitorus dan Chrissie Sagita Hutahean sebagai pasangan calon dalam Pilkada. 
Akibat keputusan yang diambil oleh Panwas Kabupaten Toba Samosir, maka menimbulkan persoalan baru, yang diasumsikan bahwa keputusan tersebut telah melampaui kewenangannya sebagai penyelenggara pemilu di daerah. Mencermati ketentuan yang terdapat dalam Pasal 13 huruf j UU No. 8 Tahun 2015, kewenangan untuk menetapkan pasangan calon Bupati dan Wakil Bupati adalah kewenangan KPU, bukan kewenangan Panwas. Keputusan penetapan pasangan calon Bupati dan Wakil Bupati yang dibuat oleh Panwas Kabupaten Toba Samosir, merupakan tindakan yang melampaui batas kewenangannya atau dengan kata lain sebagai tindakan di luar yurisdiksinya, sehingga keputusan tesebut merupakan tindakan yang melanggar etika penyelenggaraan pemilu, yaitu terkait dengan penerapan asas kepastian hukum sebagaimana tertuang dalam Pasal 5 jo Pasal 11 Peraturan Kode Etik Pemilu. Ketentuan yang terkait dengan kewenangan Panwas Kabupaten/Kota yang diatur dalam UU No. 8 Tahun 2015, sudah diatur secara jelas, dengan demikian dapat dikatakan bahwa penerapan asas kepastian hukum dalam penyelesaian sengketa pemilu oleh Panwas Kabupaten Toba Samosir tidak terpenuhi.

\section{E. Penutup}

Adanya fakta dan pengalaman bahwa di Kabupaten Toba Samosir telah terjadi pelanggaran etika penyelenggaraan pemilu yang terkait dengan asas kepastian hukum dalam penyelesaian sengketa pemilu, perlu kiranya dilaksanakan pembinaan di jajaran Panwas Kabupaten/Kota tentang kewenangan dalam penyelesaian sengketa pemilu, sehingga para penyelenggara pemilu (khususnya Panwas) dapat memahami, mempedomani serta mengindahkan asas-asas, prinsip-prinsip dasar, dan pelaksanaan prinsip-prinsip dasar pemilu sebagaimana yang ditetapkan dalam Peraturan Kode Etik Pemilu, serta peraturanperaturan atau regulasi-regulasi lain yang terkait dengan penyelenggaraan pemilu. 


\section{DAFTAR PUSTAKA}

Budiono Kusumohamidjojo (1999) Ketertiban yang Adil (Problematik Filsafat Hukum), Jakarta: Grasindo.

Franz Magnis Suseno (2001) Etika Politik, Jakarta: Gramedia Pustaka Utama.

Pusat Bahasa Departemen Pendidikan Nasional (2002) Kamus Besar Bahasa Indonesia, Jakarta: Balai Pustaka.

Sudikno Mertokusumo (1993) Bab-bab tentang Penemuan Hukum, Bandung: Citra Aditya Bakti. 